\title{
The Study of the Development of Urban and Rural Preschool Education in Justice - Orientation
}

\author{
Wenfei Jiang \\ Hangzhou normal university \\ Zhejiang province, china \\ Jwf19910105@126.com
}

\author{
Huansong Yang* \\ Hangzhou normal university \\ Zhejiang province, china \\ hzjyhs@163.com \\ *Corresponding author
}

\author{
Lihua $\mathrm{Xu}$ \\ Hangzhou normal university \\ Zhejiang province, china \\ Xulihua58@hotmail.com
}

\begin{abstract}
The unbalance development of Preschool Education in Urban and Rural is the main restraint to the development of Preschool Education. With the development of society, developing Justice Preschool Education is becoming the essential value appeal. Preschool Education in the Justiceorientation includes the Justice of educational starts, the Justice of educational process, the Justice of educational results. Via educational laws, finical assistance, building the high level teachers, we can build the Preschool Education in Urban and Rural in Justice - orientation, which can prompt the development of Preschool Education in our country.
\end{abstract}

Keywords-justice; urban and rural; preschool education; balance; development

\section{INTRODUCTION}

In the process of increasing the democratic construction, justice has become the basic value apple of the whole society.

The purpose of developing preschool education fairly are satisfying every young children's needs in education, providing each child a equal resources and the healthy growth environment. However, because of the imbalance in economy, the pre children in rural areas did not have the same opportunity to enjoy the same resources as urban areas. Thus, rural pre children get behind at the starting of life. The imbalance development of preschool education between urban and rural areas has become the main obstacle which instructs the fair preschool education.

\section{FAIRNESS AND FAIR EDUCATION}

Fairness is one of highest value which have always been pursued by human being. According to the explanation in Chinese Dictionary, fair is "doing things reasonable, impartial". Fairness is a rationale judgment value which is used in interest relationship and resources allocation. The essence of fairness is justice and rationality. The ethicists Alasdair MacIntyre (1957) pointed: "Fairness is giving everyone the duty due to it, beyond yourself and is not a form of incompatible with their due to treat anyone an arrangement [1]". Beauchamp believe that:"If someone give others the things he should have, thus the former behavior to the latter's is the justice[2]".

The education builded under the fairness means that education development obeys the basic principles of justice and the state education resources are configured according to it. On the macro, education fairness refers to all school-age children to enjoy equal education opportunities and education resources and obtain reasonable education results. On the microscopic, it means to treat every student equally [3]. Education justice is divided into three levels in general, including the starting, middle and ending in education, as the fairness of educational starts, the fairness of educational process the fairness of educational results.

\section{The Connotation of The PREschool EduCATion IN FAIR - ORIENTATION}

At present, the severe opposition between urban and rural dual structure is the main contradiction in China. The preschool education in urban and rural is imbalance. Children in different regions and social class can't enjoy the fair education resources, which leads to the children in poor areas and social class entered into a vicious cycle, and living in the bottom of society. In the current imbalance development situation of urban and rural preschool education, the aim of preschool education in fair-orientation is to ensure every child have equal opportunity to receive good education, enjoying equal educational resources in the process of education, receiving the justice educational results and obtaining basic rights to be valued in a fair evaluation standards. This right is not influenced neither by their economic status and political status, also is not restricted by poor social institutions.

\section{A. The Fairness of Educational Starts}

The fairness of educational starts is the precondition of realizing fair education. From the right level, The fairness of educational starts means everyone has the same right to receive equal education as others have. It mainly refers to the fair opportunity in education. And fairness of educational starts includes two aspects: equal educational rights and equal educational opportunity.

The elements to influence the fairness of educational starts are individual's social status, economic status and the social fairness and justice.

\section{B. The Fairness of Educational Process}

The fairness of educational process means taking students different needs into account and dealing everyone fairly on the basis of satisfying the fundamental needs in education. The fairness of educational process includes two faces: 
treating students equally and treating students differently[4]. That means in the process of education, educator should consider the same needs and personal needs to prompt it's development. The fairness of educational process is the core of educational fairness, and the critical key link of realizing fair education.

Education process fairness has the two level, the macroscopic and the microscopic[5]. In the macro, it refers to the fair distribution of education rights and economic input In the micro, it refers to the fair distribution in education about specific resources. By the macro and micro fair distribution, the development of rural preschool education has the same energy as urban preschool education. Children in rural share the same educational resource as children in urban.

The justice process mainly rely on a reasonable allocation of education resources. Fair resource allocation includes the principle of equal liberty and difference principle.

\section{1) The Principle of equal liberty}

The Principle of Equal Liberty is to show everyone the rights as equal with everyone[6]. In the right allocation, we do not distinguish different educational level by one's social and economic status. Countries ensure this right with legal provisions in education.

\section{2) The difference principle}

Difference principle refers to the economic dispatch should be suitable for at least in the best interest of the beneficiaries[7]. The whole status of the preschool education in China is: rural demand for preschool education is greater than the city, but the allocation of resources was opposite. The children in rural share little education resource and they are the minimum beneficiaries of education resource allocation. Thus, investment in rural preschool education will get big returns.

The elements to influence the fairness of educational process are: facilities, site arrangement, the area of the activity room, the teachers level, book resources available for young children, environment, health situation and so on in preschool education institutions.

\section{The Fairness of Educational Results}

The fairness of educational results means students accepting the same education while eventually receiving the same academic achievement. It is the fairness in the goal[8]. The fairness of educational results is the ultimate value pursuit in education. The fairness of education starts and the fairness of education process are the essential condition of the fairness of educational results, but not a sufficient condition. It is influenced by own efforts and fair standard, besides the starts and process fair of education.

\section{THE UNFAIR STATUS OF URBAN AND RURAL PRESCHOOL EDUCATION}

Due to the influence of economic, political and social environment, the development of China's urban and rural preschool education issues highlights. That mainly are reflected in three aspects.

\section{A. The Unfairness of Educational Starts}

The root causes of unfairness of educational starts are the difference of economic status and political status. The unfairness of educational starts includes the unequal right for preschool children to accept preschool education and inequality in chance.

The unfairness of educational starts is reflected by the enrollment in kindergarten. According to the survey, the enrollment in preschool education reached on 56.6\% in 2010 in China, which was $5.7 \%$ higher than that of 2009 . In economical developed areas, such as Beijing, Tianjin, Shanghai, the enrollment in preschool education have reached more than $90 \%$. The child aged 3-6 enrolled in preschool education over $98 \%$. In economical developing areas, such as Henan, Xinjiang, the enrollment in preschool education have just reached $50 \%$. A large number of children in developed areas did not into kindergarten,and the opportunity to get preschool education still unequal.

The enrollment in city is higher in country. Urban children have more chances to receive high quality education than rural children, so it in not justice in urban and rural preschool education.

\section{B. The Unfairness of Educational Process}

The unfairness of educational process is the core of the influence of urban and rural preschool educational fairness. The unfairness of educational process is reflected by the imbalance distribution in finance, the differences in pupil ratio and huge difference of teachers' quality.

\section{1) The imbalance distribution in finance}

Economic investment is the basis for the development of education. Under the same condition in the economy, the investment of preschool education in urban areas is much more than in rural areas. The per fund of rural preschool children is serious shortage. The facilities in school is run-down and Lacking of high quality teacher resources. The funds for preschool education accounted for about $1.3 \%$ of public education funds, and $70 \%$ is used in urban kindergarten. Economic burden changed to the parents.

2) The significant difference pupil ratio in preschool education

The wages of teachers in rural kindergarten is low, and it do not match the teachers work. Many teachers in rural kindergarten emerge Career ennui. Good teachers choose to change career, or get into the city kindergarten, which lead to the shortage of teacher. So, the pupil ratio is much low in rural kindergartens.

The number of full-time kindergarten teachers in city is 3.09- - 3.35 times than it in country. The pupil ratio in urban kindergartens is $2.17-2.85$ times than it in rural kindergartens from 2005to2010.

The high pupil ratio is the main factor to constrain the development of rural preschool education. The teacher is also 
to be a resource. It is difficult to take all the children needs into account.

\section{3) The huge difference of teachers' quality in urban and rural preschool education}

One of the important standard of the quality of teachers is it's qualifications. Opposite with the Full-time kindergarten teachers in city, the rural kindergarten teachers' qualifications is lower overall in China. The number of postgraduate and bachelor degree teacher in urban kindergartens increased 48497 from 2002 to 2008 . However, the number in rural kindergartens is 10114 , in the other word, it is 5 times more than in rural kindergartens.

According to the survey, the number of postgraduate degree teachers in kindergarten is 1151 in 2010, and $76.5 \%$ is in urban kindergartens, $3.6 \%$ is in rural kindergartens. As for the bachelor degree teacher, $54.5 \%$ is in urban kindergartens, $9.8 \%$ is in rural kindergartens. Educational level of preschool teachers in rural is much lower than it in city.

\section{The Unfairness of the Educational Results}

The unfairness of results in preschool education is reflected on the differentiation results, that is children accepted preschool education in the same way did not obtain the same knowledge and skills when they went into school. According to the survey: children in city is more prepared than in country. Rural children is much lower than urban children in Learning styles, cognitive development, general knowledge, emotion and social development.

\section{The MEASURES TO DEVElop FAIR URBAN AND RURAL PRESCHOOL EDUCATION}

\section{A. Strengthening Preschool Educational Laws}

Fairness is giving everyone deserved rights and interests, being equivalent to people in equality and to the unequal person or thing differently. In law society, the most powerful weapons is the law. To guarantee children have the equal fundamental right to receive preschool education, many developed countries formulate relevant laws and regulations that relate to preschool education. In America, they are

《Child Care Act》 and 《Child Care and Development Block Grant Act 》. In England, it is 《Children Act》.

In China, the 《Compulsory Education Law》 and its amendments do not have specific provision to urban and rural children's right to education. In the 18th CPC National Congress, there was a proposal to build Special 《Preschool Education Law》 to Specificate development of preschool education.

The basic approaches to develope fair urban and rural preschool education is Strengthening the legislation of preschool education and strictly enforcing it, protecting the rights of children to be educated, making them enjoy equal opportunity in school.

\section{B. Financial Investment Differentiation}

Financial investment obeys differentiation method, and Lean to the rural preschool education. In China, educational investment consists of national, local government and private investment. National and local government investment are public, whereas, private investment is profitability. In the three parts, national finance is dominant, local government is less, private investment is minimum. In addition to increasing the amount of preschool education finance, it is necessary to allocate money in rural and urban areas rationally.

The government should formulate reasonable fiscal policy, increase educational financial proportion, optimize the structure of urban and rural financial input in preschool education. Local government build specific preschool education budget. The educational funding leak to rural preschool education.

\section{Improving Teacher's Level}

The quality of teachers is the main restrain to develope rural preschool education.

\section{1) Improve the treatment of rural preschool teachers}

More salary can give teachers self sense of value. The main reason of rural preschool teachers changed career is low treatment. The characteristic of children determines the complex work of the preschool teachers. The salary does not match the their hard work.

In China, teachers in compulsory educational stage imply Merit Pay. Based on guaranteeing the urban and rural teacher salary on the same level, it can leaks to rural teacher. The government should widen the ways of finical, protect rural preschool teachers' minimum wage standard and improve the welfare of rural preschool teachers. At the same time, completing the teachers' preparation system can satisfy teachers' expectations.

\section{2) Afford more chances to improve themselves}

《Teachers Law of the People's Republic of China》 believes teachers have basic rights to communicate and study. Because of the environment in country, rural preschool teachers have no opportunity to share the rights. It is to be the main hinder factors to improve the quality of teachers.

To improve the quality of preschool teachers, government acts "National Training Plan" via Normal Colleges and Universities. Rural kindergarten teachers take part in this training and they radiate to other teachers. This is a good measure to improve the quality of teachers.

Developing the urban and rural preschool education in fair-orientation is to improve the quality of the rural preschool education, and promote the coordinated development of preschool education in the rural and urban areas.

\section{ACKNOWLEDGEMENTS}

This study is supported by People's Republic of China Ministry of Education, Humanities and Social Sciences Key Research Base, 2011 Major Research Project - - Chinese Teacher Training for Primary Education Studies. NO.11JJD880033. At the same time, it is also funded by 
Revitalization Project in Humanities and Social Science of Hangzhou Normal University.

Corresponding Author: Huansong Yang.

\section{REFERENCES}

[1] Alasdair MacIntyre, "Whose justice? what is reasonable?", Beijing: Contemporary China Publishing House, 1994, p56.

[2] T.L. Beauchamp, "The Philosophy of Ethics", Beijing: Chinese Social Science Press, 1990, pp327-328.

[3] Shanmai Wang, "Analysis Framework and Evaluation Indicators of Education Equity, No. 3. Journal of Beijing Normal University, 2008.

[4] Xingyu Lv, "The meaning of the fairness of Educational Process",no.04. The Theory and Practice of Education, 2011.

[5] John Rawls,"A Theory of Justice”, Beijing: Chinese Social Science Press, 2012, p6.

[6] John Rawls, "A Theory of Justice”, Beijing: Chinese Social Science Press, 2012, p6.

[7] [Shenyue Yingzi, "the Study of Equity in Educational Outcome from the Perspective of Social Level", Nanjing normal university,2011.

[8] Huanhuan $\mathrm{Li}$, “ The Problems and The Measures in The Balance Development of Urban and Rural Preschool Education", No.07. Basic Education Research, 2011. 